\title{
PENGARUH LINGKUNGAN KERJA FISIK DAN BUDAYA ORGANISASI TERHADAP KEPUASAN KERJA KARYAWAN DI PT. BANK TABUNGAN NEGARA CABANG MEDAN
}

\author{
Fauzia Agustini ${ }^{1{ }^{*}}$, Aidil Putra ${ }^{2)}$, Sastika Dumenta ${ }^{\text {3) }}$ \\ 1) Fakultas Ekonomi, Universitas Negeri Medan \\ 2) Manajemen, STIE PMCI \\ 3) Fakultas Ekonomi, Universitas Negeri Medan \\ *Penulis korespondensi: fauziaagustini24@yahoo.com
}

\begin{abstract}
Penelitian ini bertujuan untuk mengetahui Pengaruh Lingkungan Kerja Fisik dan Budaya Organisasi Terhadap Kepuasan Kerja Karyawan di PT. Bank Tabungan Negara Cabang Medan. Penelitian ini dilakukan pada PT. Bank Tabungan Negara Cabang Medan dengan jumlah populasi sebanyak 88 orang dengan menggunakan Total Sampling. Teknik pengumpulan data yang digunakan adalah melalui koesioner (angket) yaitu dengan cara menyebarkan kuesioner kepada sampel (responden) dan mengumpulkannya kembali. Teknik analisis data yang digunakan adalah Regresi Linier. Sebelum data diregresikan maka terlebih dahulu di uji keterkaitannya antara variabel independen datanya dengan uji normalitas data, multikolinearitas, dan heterokedasitas. Untuk mengetahui kontribusi faktor lingkungan kerja fisik, budaya organisasi, terhadap kepuasan kerja karyawan digunakan rumus determinan $\left(\mathrm{R}^{2}\right)$. Dari hasil pegujia hipotesis maka dapat diambil kesimpulan bahwa hipotesis diterima, yaitu terdapat pengaruh yang signifikan antara lingkungan kerja fisik dan budaya organisasi terhadap kepuasan kerja karyawan PT. Bank Tabungan Negara Cabang Medan
\end{abstract}

Keywords: Lingkungan Kerja Fisik, Budaya Organisasi, dan Kepuasan Kerja Karyawan 


\section{PENDAHULUAN}

Setiap perusahaan memiliki sumber daya manusia yang merupakan unsur yang sangat penting yang harus diperhatikan oleh pihak manajemen perusahaan. Hal ini dikarenakan sumber daya manusia merupakan satu aset besar yang dapat mempengaruhi upaya perusahaan untuk bertahan dan mencapai tujuannya. Maka dari itu, perusahaan benar-benar dituntut untuk mampu memberikan kepuasan kerja kepada seluruh karyawan yang dimilikinya. Menurut Agustini dan Harefa (2016:147) Kepuasan kerja adalah perasaan dan sikap terhadap pekerjaan yang dilakukannya, yang dapat dipengaruhi oleh berbagai macam faktor, baik faktor internal dan faktor eksternal.

Agar karyawan dapat mencapai kepuasan kerja yang optimal perusahaan harus memperhatikan faktor-faktor yang mempengaruhi kepuasan kerja karyawan. Seperti lingkungan kerja dan budaya organisasi (Mangkunegara,2005). Menurut Sedarmayanti (2007:20) berpendapat bahwa, "lingkungan kerja fisik adalah semua keadaan berbentuk fisik yang terdapat di sekitar tempat kerja yang dapat mempengaruhi karyawan baik secara langsung maupun secara tidak langsung.". Kemudian menurut Djokosantosa (2003:15) berpendapat bahwa, "budaya adalah sistem nilai-nilai yang diyakini oleh semua anggota organisasi dan yang dipelajari, diterapkan, dan dikembangkan secara berkesinambungan untuk menciptakan tujuan organisasi yang telah ditetapkan”.

Bank Tabungan Negara Cabang Medan juga telah berupaya untuk memenuhi kepuasan kerja karyawannya dengan memperhatikan banyak aspek seperti, kesempatan untuk mendapatkan promosi bagi karyawan, pemberian motivasi oleh atasan, dan penerapan budaya kerja Pola Prima yang telah mereka anut selama ini.

Namun tetap tidak bisa dipungkiri bahwa terkadang masih saja ada masalah yang terjadi, seperti tangga yang tidak memadai, kurangnya ventilasi, suara bising yang ditimbulkan oleh mesin pencetak rekening koran, gudang arsip yang berantakan, kurangnya area parkir, atasan yang sering menimbun tugas pada karyawan, turunnya semangat untuk melaksanakan briefing setiap pagi, dan lain sebagainya.

Tujuan dari penelitian ini yaitu untuk mengetahui pengaruh lingkungan kerja fisik terhadap kepuasan kerja karyawan,untuk mengetahui pengaruh budaya organisasi terhadap kepuasan kerja karyawan, dan untuk mengetahui pengaruh lingkungan kerja fisik dan budaya organisasi terhadap kepuasan kerja karyawan di PT. Bank Tabungan Negara Cabang Medan

\section{TINJAUAN PUSTAKA}

Lingkungan Kerja Fisik

Menurut Nitisemito

(2000:183),

"lingkungan kerja adalah segala sesuatu yang ada disekitar para pekerja yang dapat mempengaruhi dirinya dalam menjalankan tugasa-tugas yang diembannya". Lebih lanjut Sedarmayanti (2001:21) menyatakan bahwa, "lingkungan kerja adalah keseluruhan alat perkakas dan bahan yang dihadapi, lingkungan sekitarnya di mana seseorang bekerja, metode kerjanya, serta pengaturan kerjanya baik sebagai perseorangan maupun sebagai kelompok ". Lingkungan kerja yang baik akan memberikan kenyamanan dan dapat membangkitkan semangat kerja kepada karyawan, sehingga mereka dapat menyelesaikan tugas-tugasnya. Disamping itu, pegawai akan lebih merasa senang dan nyaman ketika bekerja apabila lingkungan perusahaannya bersih, jauh dari kebisingan, pertukaran udara cukup baik, dan peralatan serta perlengkapan yang memadai.

Sedarmayanti (2007:20) berpendapat bahwa, "lingkungan kerja fisik adalah semua keadaan berbentuk fisik yang terdapat di sekitar tempat kerja yang dapat mempengaruhi karyawan baik secara langsung maupun secara tidak langsung." Moekijat (2005:13) mengatakan bahwa lingkungan kerja yang baik adalah lingkungan kerja yang dapat mempengaruhi atau meningkatkan efisiensi kerja, antara lain: tata letak ruang kerja, cahaya di dalam ruangan, suhu dan kelembaban, dan suara yang tidak mengganggu konsentrasi kerja.

Maka dapat disimpulkan bahwa lingkungan kerja fisik adalah kondisi di dalam perusahaan yang berpengaruh pada segala aktivitas karyawan yang akan bardampak pada kepuasan kerja karyawan dalam menjalankan pekerjaannya guna mencapai tujuan perusahaan.

\section{Budaya Organisasi}

Djokosantosa (2003:15) berpendapat bahwa, "budaya adalah sistem nilai-nilai yang diyakini oleh semua anggota organisasi dan yang 
dipelajari, diterapkan, dan dikembangkan secara berkesinambungan untuk menciptakan tujuan organisasi yang telah ditetapkan".

Menurut Glaser et al (dalam Koesmono, 2005:9) mengemukakan bahwa "budaya organisasi seringkali digambarkan dalam arti yang dimiliki bersama. Pola-pola dari kepercayaan, simbolsimbol, dan ritual-ritual yang berkembang dari waktu ke waktu dan berfungsi sebagai perekat yang menyatukan organisasi”.

Menurut beberapa pendapat para ahli yang telah diuraikan sebelumnya, penulis menyimpulkan bahwa budaya organisasi menekankan pada sifat dan sikap karyawan dalam bekerja, nilai-nilai dan kesempatan terhadap rencana strategis perusahaan. Budaya organisasi telah berupaya mengukur bagaimana karyawan memandang organisasinya, apakah organisasi itu mendorong kerja tim, dan apakah organisasi itu menghargai inovasi.

\section{Penelitian Relevan}

Penelitian yang dilakukan oleh Ida Ayu (2008), dalam jurnalnya yang berjudul: "Pengaruh Motivasi Kerja, Kepemimpinan, dan Budaya Organisasi Terhadap Kepuasan Kerja Karyawan Serta Dampaknya Pada Kinerja Perusahaan (Studi Kasus Pada PT. Pei Hai Internasional Wiratama Indonesia)." dimana peneliti menggunakan program aplikasi komputer yaitu SPSS versi 13.0 dan AMOS versi 4.0 untuk pengujian data. Dengan kesimpulan: motivasi kerja berpengaruh positif dan signifikan terhadap kepuasan kerja karyawan, kepemimpinan berpengaruh negatif dan signifikan terhadap kepuasan kerja karyawan, budaya organisasi berpengaruh positif dan signifikan terhadap kepuasan kerja karyawan, motivasi kerja tidak berpengaruh signifikan terhadap kinerja perusahaan, kepemimpinan berpengaruh positif dan signifikan terhadap kinerja perusahaan, budaya organisasi berpengaruh positif dan signifikan terhadap kinerja perusahaan, dan kepuasan kerja karyawan berpengaruh positif dan signifikan terhadap kinerja karyawan.

Selanjutnya, penelitian yang dilakukan oleh Gita Sugiyarti SE, M.Si dengan judul "Pengaruh Lingkungan Kerja, Budaya Organisasi, dan Kompensaso Terhadap Kepuasan Kerja Karyawan Untuk Meningkatkan Kinerja Pegawai (Studi Pada Fakultas Ekonomi Universitas 17 Agustus 1945 Semarang)", memberi kesimpulan bahwa: lingkungan kerja
NIAGAWAN Vol 7 No 1 Maret 2018 berpengruh positif dan signifikan terhadap kepuasan kerja karyawan, budaya organisasi berpengaruh positif dan signifikan terhadap kepuasan kerja karyawan, kompensasi berpengaruh positif dan signifikan terhadap kepuasan kerja karyawan, lingkungan kerja berpengaruh positif dan signifikan terhadap kinerja pegawai, kepuasan kerja berpengaruh positif dan signifikan terhadap kinerja karyawan.

\section{Kepuasan Kerja}

Menurut Dole dan Schroeder (dalam Koesmono, 2005) berpendapat bahwa "kepuasan kerja dapat diidentifikasikan sebagai perasaan dan reaksi individu terhadap lingkungan pekerjaannya". Lebih lanjut Koesmono (2005) mengemukakan bahwa "kepuasan kerja merupakan penilaian, perasaan atau sikap seseorang atau karyawan terhadap pekerjaannya dan berhubungan dengan lingkungan kerja, jenis pekerjaan, kompensasi, hubungan antar teman kerja, hubungan sosial di tempat kerja, dan sebagainya. Sehingga dapat dikatakan bahwa kepuasan kerja adalah dipenuhinya beberapa keinginan dan kebutuhannya melalui kegiatan kerja atau bekerja".

Dari beberapa pengertian tersebut, maka dapat disimpulkan bahwa kepuasan kerja merupakan suatu ungkapan sikap karyawan terhadap pekerjaan dan lingkungan kerjanya. Kepuasan kerja ini akan timbul bila karyawan merasa apa yang seharusnya diterima dari pekerjaannya telah sesuai dengan apa yang telah dilakukan atas pekerjaan tersebut. Bila karyawan memiliki tingkat kepuasan kerja yang tinggi, maka karyawan akan menunjukkan sikap yang positif. Sedangkan bila karyawan mempunyai tingkat kepuasan kerja yang rendah, maka karyawan tersebut akan menunjukkan sikap negatif terhadap pekerjaannya.

\section{Hipotesis}

Hipotesis adalah suatu penjelasan sementara tentang perilaku, fenomena, atau keadaan tertentu yang akan terjadi. Berdasarkan kerangka teori dan kerangka berfikir sebagaimana telah diutarakan, maka hipotesis dalam penelitian ini adalah:

1. Terdapat pengaruh lingkungan kerja fisik terhadap kepuasan kerja karyawan di PT. Bank Tabungan Negara Cabang Medan.

2. Terdapat pengaruh budaya organisasi terhadap kepuasan kerja karyawan di PT. Bank Tabungan Negara Cabang Medan. 
3. Terdapat pengaruh antara lingkungan kerja fisik dan budaya organisasi terhadap kepuasan kerja karyawan di PT. Bank Tabungan Negara Cabang Medan.

\section{METODE PENELITIAN}

Penelitian dilaksanakan di Kantor PT. Bank Tabungan Negara Cabang Medan yang berlokasi di jalan Pemuda No. $10^{\mathrm{A}}$ Medan, Sumatera Utara.

Populasi dalam penelitian ini adalah seluruh karyawan Bank Tabungan Negara Cabang Medan yang berjumlah 88 orang.

Dalam penelitian ini pengambilan sampel dilakukan dengan cara total sampling. "Total sampling merupakan teknik penentuan sampel bila semua anggota populasi digunakan sebagai sampel (Sugiyono, 2005:93)".

Variabel bebas (X1) yaitu lingkungan kerja fisik. Sedarmayanti (2001:21) menyatakan bahwa lingkungan kerja fisik adalah semua keadaan berbentuk fisik yang terdapat di sekitar tempat kerja yang dapat mempengaruhi karyawan baik secara langsung maupun secara tidak langsung. Indikator Lingkungan Kerja Fisik yaitu penerangan, suhu udara, suara bising, penggunaan warna dan dekorasi, suasana kerja, tersedianya fasilitas untuk karyawan, dan keamanan kerja.

Variabel bebas (X2) yaitu budaya organisasi. Budaya organisasi adalah suatu pola asumsi dasar yang diciptakan, ditemukan, atau dikembangkan oleh kelompok tertentu sebagai pembelajaran untuk mengatasi masalah adaptasi eksternal dan internal yang resmi dan terlaksana dengan baik, dan oleh karena itu diajarkan/ diwariskan kepada anggota-anggota baru sebagai cara yang tepat memahami, memikirkan, dan merasakan terkait dengan masalah tersebut (Schein dalam Tika, 2006:2).

Indikator Budaya Organisasi (X2) yaitu Inovasi dan pengambilan resiko, perhatian terhadap detail, orientasi terhadap hasil, orientasi terhadap individu, orientasi pada tim dan agresivitas

Variabel terikat (Y) yaitu kepuasan kerja karyawan. Kepuasan kerja merupakan penilaian, perasaan atau sikap seseorang atau karyawan terhadap pekerjaannya dan berhubungan dengan lingkungan kerja, jenis pekerjaan, kompensasi, hubungan antar teman kerja, hubungan sosial di tempat kerja, dan sebagainya. Sehingga dapat dikatakan bahwa kepuasan kerja adalah dipenuhinya beberapa keinginan dan
NIAGAWAN Vol 7 No 1 Maret 2018 kebutuhannya melalui kegiatan kerja atau bekerja (Koesmono, 2005).

Indikator Kepuasan Kerja Karyawan (Y) yaitu Pembayaran gaji dan upah, pekerjaan itu sendiri, rekan kerja, promosi, dan supervisi..

Teknik pengumpulan data yang digunakan dalam penelitian ini adalah observasi, studi dokumen, dan angket/ kuesioner. Dengan skala pengukuran yang digunakan yaitu interval.

Metode yang digunakan untuk menganalisis data yaitu Analisis Regresi Berganda. Analisis regresi berganda (Multiple Linier Regresion) untuk mengetahui pengaruh antara variabel bebas (lingkungan kerja fisik dan budaya organisasi) terhadap variabel terikat (kepuasan kerja karyawan).

Pada penelitian ini menggunakan analisis regresi berganda dimana secara umum data hasil pengamatan Kepuasan dipengaruhi oleh beberapa variabel bebas Lingkungan Kerja Fisik dan Budaya Organisasi. Rumus umum dari regresi berganda yaitu :

$$
\mathbf{Y}=\mathbf{a}+\mathbf{b}_{1} \mathbf{X}_{1}+\mathbf{b}_{2} \mathbf{X}_{2}+\ldots . . . . e
$$

Uji Hipotesis yang digunakan yaitu Uji $F$ (Simultan) dan Uji t (Parsial)

\section{HASIL DAN PEMBAHASAN}

\section{Pengujian Analisis Regresi Linear Berganda}

Persamaan regresi berganda secara umum adalah.

$$
\mathbf{Y}=\mathbf{a}+\mathbf{b}_{1} \mathbf{X}_{1}+\mathbf{b}_{2} \mathbf{X}_{2}
$$

\section{Tabel 1. Koefisien Regresi}

Coefficients $^{a}$

\begin{tabular}{|l|c|c|c|c|c|}
\hline & \multicolumn{2}{|c|}{$\begin{array}{c}\text { Unstandardized } \\
\text { Coefficients }\end{array}$} & $\begin{array}{c}\text { Standardized } \\
\text { Coefficients }\end{array}$ & & \\
\cline { 2 - 4 } Model & $\mathrm{B}$ & $\begin{array}{c}\text { Std. } \\
\text { Error }\end{array}$ & Beta & $\mathrm{T}$ & Sig. \\
\hline $\begin{array}{l}1 \text { (Constant) } \\
\text { Lingkungan } \\
\text { KerjaFisik }\end{array}$ & .343 & 3.727 & & .092 & .927 \\
$\begin{array}{l}\text { BudayaOrg } \\
\text { anisasi }\end{array}$ & .234 & .095 & .464 & 5.089 & .000 \\
\hline
\end{tabular}

Dari hasil pengolahan data, maka dapat dibuat persamaan regresinya. Persamaan regresi tersebut adalah :

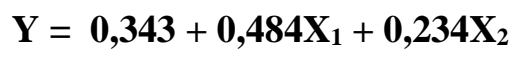

- Konstanta sebesar 0,343 dapat diartikan bahwa Y akan bernilai sebesar 0,343 pada saat X1 dan X2 bernilai nol (tidak ada).

- Koefisien regresi $X_{1}$ sebesar 0,484 menyatakan bahwa kenaikan satu satuan X1 akan meningkatkan Y sebesar 0,484. 
Koefisien regresi $\mathrm{X}_{2}$ sebesar 0,234 menyatakan bahwa kenaikan satu satuan X2 akan meningkatkan Y sebesar 0,234.

\section{Pengujian Hipotesis}

Pengujian Hipotesis secara Simultan menggunakan Uji - F

Uji hipotesis secara simultan diperlukan untuk mengetahui apakah model regresi sudah benar atau tidak. Uji hipotesis menggunakan angka F, yang diperoleh dari tabel Anova berikut ini :

Tabel 2 Uji F

ANOVAa

\begin{tabular}{|l|r|r|r|r|r|}
\hline Model & $\begin{array}{c}\text { Sum of } \\
\text { Squares }\end{array}$ & Df & $\begin{array}{c}\text { Mean } \\
\text { Square }\end{array}$ & F & Sig. \\
\hline 1 Regression & 476.598 & 2 & 238.299 & 18.161 & $.000^{\mathrm{b}}$ \\
$\begin{array}{l}\text { Residual } \\
\text { Total }\end{array}$ & 1115.299 & 85 & 13.121 & & \\
& 1591.898 & 87 & & & \\
\hline
\end{tabular}

Pengujian hipotesis dilakukan dengan cara membandingkan besarnya angka $\mathrm{F}$ penelitian dengan $\mathrm{F}$ tabel, dengan kriteria sebagai berikut : Jika $\mathrm{F}$ hitung > $\mathrm{F}$ tabel, maka hipotesis diterima.

Jika F hitung < F tabel, maka hipotesis ditolak. Berdasarkan tabel diatas angka $F$ penelitian yang diperoleh dari hasil perhitungan adalah sebesar 18.161. Sedangkan angka $F$ tabel dihitung dengan ketentuan yaitu taraf signifikansi $95 \%$ dan alpha 5\%,serta derajat kebebasan (dk) dengan ketentuan n-2 $=88-2=86$. Dari ketentuan tersebut diperoleh angka F tabel: 3,10 Dengan demikian diperoleh nilai $\mathrm{F}_{\text {hitung }}=18.161$, dan $F_{\text {tabel }}=3,10$. Karena $F_{\text {hitung }}>F_{\text {tabel }}$ yang berarti bahwa hipotesis diterima, sehingga dapat disimpulkan bahwa terdapat pengaruh yang signifikan secara simultan antara Variabel $\mathrm{X}_{1}$ dan Variabel $X_{2}$ terhadap Variabel $Y$.

\section{Pengujian Hipotesis Secara Parsial menggunakan uji - $\mathbf{t}$ \\ Uji hipotesis secara parsial diperlukan untuk mengetahui seberapa jauh pengaruh satu variable independen secara individual dalam menerangkan variabel dependen.}

\section{Pengujian Lingkungan Kerja Fisik terhadap Kepuasan Kerja Karyawan secara parsial.}

Secara parsial, uji statistik yang digunakan adalah uji t. Hasil perhitungan SPSS diperoleh angka thitung sebesar 5,089. Untuk memperoleh
NIAGAWAN Vol 7 No 1 Maret 2018 besarnya $\mathrm{t}$ tabel dilakukan perhitungan sebagai berikut:

Taraf signifikansi 95\% dan alpha 5\%, serta derajat kebebasan $(\mathrm{dk})$ dengan ketentuan $\mathrm{dk}=\mathrm{n}$ $\mathrm{k}$ atau $88-3=85$. Dengan keterangan bahwa $\mathrm{n}$ adalah jumlah dari sample dan $\mathrm{k}$ menyatakan banyaknya jumlah variabel penelitian. Dari ketentuan tersebut diperoleh angka $\mathrm{t}$ tabel sebesar $\mathbf{1 , 9 8 8}$.

Kriteria uji hipotesis adalah sebagai berikut : -Jika $\mathrm{t}$ hitung $>\mathrm{t}$ tabel, maka hipotesis diterima. -Jika t hitung < t tabel, maka hipotesis ditolak.

Berdasarkan tabel Coefficients (lihat lampiran), diperoleh hasil 5,089 > 1,988, maka hipotesis diterima. Artinya, terdapat pengaruh yang signifikan dari Lingkungan Kerja Fisik terhadap Kepuasan Kerja Karyawan.

2. Pengujian Budaya Organisasi terhadap Kepuasan Kerja Karyawan secara parsial.

Secara parsial, uji statistik yang digunakan adalah uji t. Hasil perhitungan SPSS diperoleh angka thitung sebesar 2,766. Untuk memperoleh besarnya t tabel dilakukan perhitungan sebagai berikut:

Taraf signifikansi 95\% dan alpha 5\%, serta derajat kebebasan $(\mathrm{dk})$ dengan ketentuan $\mathrm{dk}=\mathrm{n}$ $\mathrm{k}$ atau $88-3=85$. Dengan keterangan bahwa $n$ adalah jumlah dari sample dan $\mathrm{k}$ menyatakan banyaknya jumlah variabel penelitian. Dari ketentuan tersebut diperoleh angka $t$ tabel sebesar 1,988.

Kriteria uji hipotesis adalah sebagai berikut : -Jika t hitung > t tabel, maka Hipotesis diterima -Jika t hitung < t tabel, maka Hipotesis ditolak Berdasarkan tabel Coefficients (lihat lampiran), diperoleh hasil 2,766 > 1,988, maka hipotesis diterima. Artinya, terdapat pengaruh yang signifikan dari Lingkungan Kerja Fisik terhadap Kepuasan Kerja Karyawan.

\section{Koefisien Determinasi (R Square)} Tabel 3. Koefisien Determinasi

Model Summary ${ }^{b}$

\begin{tabular}{|l|l|l|l|l|l|l|l|}
\hline \multirow{2}{*}{ Model } & \multirow{2}{*}{$\mathrm{R}$} & $\mathrm{R}$ & Adjusted & $\begin{array}{l}\text { Std. Error } \\
\text { of the }\end{array}$ & \multicolumn{3}{|c|}{ Change Statistics } \\
\hline Square & R Square & Estimate & Change & Change & df1 \\
\hline 1 & $.547^{\mathrm{a}}$ & .299 & .283 & 3.62232 & .299 & 18.161 & 2 \\
\hline
\end{tabular}

Determinan digunakan untuk mengetahui seberapa besar variabel independen mampu menjelaskan pengaruh variabel dependen. Dari tabel dapat diketahui besarnya angka $\mathrm{R}^{2}$ adalah 0,299 yang berarti variabel $X 1$, dan $X 2$, 
menjelaskan pengaruh terhadap variabel $\mathrm{Y}$ sebesar 29.9\% ( $\mathrm{R}^{2}$ X 100\%; 0.299 X $100 \%=$ $29.9 \%)$ sedangkan sisanya $70.1 \%\left(100 \%-\mathrm{R}^{2}\right)$ dijelaskan oleh variabel - variabel lain di luar model penelitian ini.

\section{Pembahasan Hasil Penelitian}

Berdasarkan hasil angket/kuesioner penelitian, diketahui bahwa lingkungan kerja fisik pada perusahaan belum sepenuhnya baik. Hal ini sesuai dengan hasil deskriptif kuesioner responden, dan juga dari observasi yang telah dilakukan oleh penulis.

Analisis data variabel lingkungan kerja fisik dalam penelitian ini memberikan hasil yang signifikan terhadap kepuasan kerja karyawan, yang artinya jika lingkungan kerja fisik semakin baik maka akan berpengaruh terhadap kepuasan kerja karyawan. Hal ini didukung oleh penelitian terdahulu yang dilakukan oleh Sugiyarti (2012) yang mengatakan bahwa, fenomena yang terjadi di lapangan menunjukkan bahwa lingkungan kerja fisik berpengaruh secara positif dan signifikan terhadap kepuasan kerja karyawan.

Hasil angket mengenai variabel budaya organisasi juga menyatakan kesimpulan yang sama. Dibuktikan juga dengan adanya observasi langsung yang dilakukan oleh penulis ke lokasi penelitian. Selama melakukan observasi penulis menemukan hal-hal seperti kurangnya komunikasi antar karyawan, masih ditemukannya nasabah yang komplain bahkan marah pada pihak bank, dan lain sebagainya. Penulis menduga bahwa hal tersebut terjadi akibat kurang baiknya budaya organisasi yang ada di dalam perusahaan.

Analisis data variabel budaya organisasi dalam penelitian ini memberikan hasil yang signifikan terhadap kepuasan kerja karyawan. Artinya jika budaya organisasi semakin baik maka akan berpengaruh terhadap kepuasan kerja karyawan. Hal ini didukung juga oleh penelitian terdahulu yang dilakukan oleh Hadi (2006), yang memberi kesimpulan bahwa diketahui terdapat hubungan yang erat antara budaya organisasi terhadap kepuasan kerja karyawan.

Berdasarkan hasil penelitian terbukti bahwa lingkungan kerja fisik dan budaya organisasi bersama-sama mempunyai pengaruh yang signifikan terhadap kepuasan kerja karyawan PT. Bank Tabungan Negara Cabang Medan.

\section{KESIMPULAN DAN SARAN}

Berdasarkan hasil analisis dan pembahasan yang telah dilakukan dalam penelitian ini, maka terdapat beberapa kesimpulan sebagai berikut :

1. Rumusan masalah dalam penelitian ini sudah terjawab melalui hasil perhitungan uji parsial dan simultan, yang keduanya memberikan kesimpulan bahwa variabel bebas masing-masing memiliki pengaruh yang signifikan terhadap variabel terikat, dan variabel bebas secara bersama-sama memiliki pengaruh yang signifikan terhadap variabel terikat.

2. Hasil perhitungan regresi memberi kesimpulan bahwa nilai konstanta pada variabel terikat akan bernilai sebesar 0,343 pada saat varibel bebas bernilai nol (tidak ada). Kemudian, koefisien regresi variabel bebas pertama menyatakan bahwa setiap kenaikan satu satuanya, akan meningkatkan variabel terikat sebesar 0,484. Selanjutnya, koefisien regresi variabel bebas kedua menyatakan bahwa setiap kenaikan satu satuannya akan meningkatkan variabel terikat sebesar 0,234.

3. Diketahui besarnya angka pada koefisien determinasi adalah 0.299, memberi pengertian bahwa variabel bebas berpengaruh sebesar $29,9 \%$ terhadap variabel terikat.

\section{Saran}

Berdasarkan penelitian yang telah dilaksanakan, maka penulis mengemukakan beberapa saran sebagai berikut ini:

1. Hasil penelitian menunjukkan bahwa lingkungan kerja fisik memiliki pengaruh terhadap kepuasan kerja karyawan. Hal ini memberi arti bahwa pihak pimpinan ataupun manajemen PT. Bank Tabungan Negara Cabang Medan harus lebih memperhatikan lingkungan kerja fisik perusahaan seperti pengoptimalan penggunaan jendela, memperhatikan area parkir, tempat arsip, suara bising, pencahayaan, serta suasana kerja, dalam upaya meningkatkan kepuasan kerja karyawan.

2. Hasil penelitian juga menunjukkan bahwa budaya organisasi juga memiliki pengaruh terhadap peningkatan kepuasan kerja karyawan. Oleh karena itu, pimpinan harus memperhatikan dan juga memastikan 
bahwa penerapan budaya organisasi dan bentuk-bentuk penghargaan yang berlaku telah berjalan sesuai dengan prosedur yang ada di perusahaan sehinngga para karyawan merasa puas dan semakin termotivasi untuk terus meningkatkan kinerja dan prestasi kerja mereka.

3. Penelitian ini masih bersifat umum, karena terlihat masih banyak faktor lain yang mempengaruhi kepuasan kerja karyawan, maka penulis menyarankan kepada peneliti selanjutnya untuk menggunakan variabel lain selain variabel dalam penelitian ini seperti; Penghargaan, Kebutuhan fisiologis, Keamanan dan keselamatan, Tingkat pendidikan atau latihan, Etos kerja, serta Kesejahteraan karyawan untuk diteliti dan lebih memperdalam ruang lingkup penelitian pada masa yang akan datang.

4. Bagi peneliti selanjutnya, jika penelitian ini digunakan sebagai referensi, disarankan agar dapat menambah atau memperdalam ruang lingkup penelitian melalui literaturliteratur yang lebih lengkap tentang lingkungan kerja fisik dan budaya organisasi dalam mempengaruhi kepuasan kerja karyawan.

\section{REFERENSI}

Brahmasari, Ida Ayu., Agus Suprayetno. 2008. Pengaruh Motivasi Kerja, Kepemimpinan dan Budaya Organisasi Terhadap Kepuasan Kerja Karyawan serta Dampaknya pada Kinerja Perusahaan (Studi Kasus pada PT. Pei Hai Internasional Wiratama Indonesia). Jurnal: Manajemen dan kewirausahaan 10 (2): 124-135

Djokosantoso, Moeljono . 2003. Budaya Korporat dan Keunggulan Korporasi, ElexMedia Komputindo, Jakarta

Fauziah, Agustini dan Harefa, Soviani Yosefhine. 2016. Analisis Komunikasi dan Pengaruhnya terhadap Kepuasan Kerja Pegawai Pada Badan Penanaman Modal dan Promosi Sumatera Utara. Jurnal Komunikasi dan Pembangunan Vol.17 No. 2 hal 143-154.

Koesmono. 2005. Pengaruh Budaya Organisasi terhadap Motivasi dan Kepuasan Kerja SertaKinerja Karyawan. Jurnal
NIAGAWAN Vol 7 No 1 Maret 2018

Manajemen dan Kewirausahaan Vol.7 No.2 September 2005. 171-188.

Moekijat. (2005). Manajemen personalia dan sumber daya manusia. Bandung: Mandar Maju

Nitisemito, Alex S.. 2000. Manajemen Personalia: Manajemen Sumber Daya Manusia, Ed. 3. Ghalia Indonesia, jakarta.

Serdamayanti. 2001. Sumber Daya Manusia dan Produktivitas Kerja. Jakarta: Mandar Maju.

Serdamayanti. 2001. Sumber Daya Manusia dan Produktivitas Kerja (Reformasi Birokrasi dan Manajemen PNS).Ed1 Bandung: Refika Aditama.

Sugiarti, Gita. 2012. Pengaruh Lingkungan Kerja, Budaya Organisasi dan Kompensasi Terhadap Kepuasan Kerja Untuk Meningkatkan Kinerja Pegawai. Fakultas Ekonomi Universitas 17 Agustus Semarang. Jurnal: Untagsmg 1 (2): 73-83

Tika, P. (2006). Budaya Organisasi Dan Peningkatan Kinerja Perusahaan. PT Bumi Aksara. Jakarta. 